\title{
Decreased expression of SRY-box containing gene 30 is related to malignant phenotypes of human bladder cancer and correlates with poor prognosis
}

Yang Liu ${ }^{1,2+}$, Han Wang ${ }^{2+}$, Jianhua Zhong ${ }^{2}$, Chenglong Wu², Gang Yang ${ }^{2}$, Yuantang Zhong ${ }^{2}$, Jinghua Zhang ${ }^{2}$ and Aifa Tang ${ }^{2^{*}}$ (D)

\begin{abstract}
Background: In human pulmonary malignancies, the SRY-box containing gene 30 (SOX30) is a known cancersuppressing gene. Nevertheless, its molecular role and clinical effects remains unknown in bladder cancer.

Methods: SOX30 mRNA expression was quantified in bladder cancer tissue, paired adjacent normal tissue, and cell lines with qRT-PCR. SOX30 protein expression in BC tissue and cell lines was evaluated via western blotting and immunohistochemistry. In addition, the clinical and prognostic significance of SOX30 in BC were assessed using Kaplan-Meier analysis. Furthermore, we measured cell migration and invasion, cell proliferation and cell apoptosis by means of a Transwell assay, cell counting kit-8 along with flow cytometry, respectively.

Results: Expression levels of SOX30 were markedly lower in BC cells and tumor tissues than in adjacent noncancerous tissues. Moreover, clinicopathological analyses showed that low SOX30 expression was positively related to an advanced tumor, node, and metastasis (TNM) stage. Furthermore, low SOX30 expression conferred reduced survival rates $(P<0.05)$. Functional analyses revealed that SOX30 overexpression attenuated cell proliferation, invasion, and migration, while promoting apoptosis in BC cells.
\end{abstract}

Conclusions: SOX30 displays tumor suppressive behavior, warranting future investigations into its therapeutic potential in the treatment of $\mathrm{BC}$.

Keywords: Bladder cancer, SOX30, Proliferation, Invasion, Apoptosis, Therapeutic target

\section{Background}

Bladder cancer $(\mathrm{BC})$ lays claim to being the fifth most common carcinoma, representing a genitourinary tract tumor that occurs most frequently in men within developed countries [1-4]. BC may be clinically categorized into muscle-invasive $\mathrm{BC}$ (MIBC) or non-muscle-invasive $\mathrm{BC}$ (NMIBC) [5]. An estimated 70\% of NMIBC patients have a high recurrence rate (50-70\%) after transurethral resection, and approximately one-third of patients diagnosed with $\mathrm{BC}$ will progress to metastatic disease [3, 5-7].

\footnotetext{
* Correspondence: tangaifa2004@163.com

†Yang Liu and Han Wang contributed equally to this work

${ }^{2}$ Department of Urinary Surgery, Shenzhen Second People's Hospital, The

First Affiliated Hospital of Shenzhen University, Shenzhen, China

Full list of author information is available at the end of the article
}

Although improvements in therapeutic methods and drugs have been implemented in recent years, the overall survival rate of $\mathrm{BC}$ patients has not observably improved because of the high rate of metastasis and recurrence [2, $4,8,9]$. Therefore, there is an urgent need to explore new tumor markers and therapeutic targets for BC.

The Y chromosome contains a mammalian sex determining region $Y(S R Y)$ gene that contains instructions for synthesizing a transcription factor with the HMG-box region, DNA-binding domain of 79 amino acids in length [10-12]. Based on sequence similarity to the HMG domain of Sry, at least $50 \%$ of Sox family members have been identified [13, 14]. Numerous earlier studies have shown that Sox proteins are essential for embryogenesis and development, including biological sex differentiation and

(c) The Author(s). 2018 Open Access This article is distributed under the terms of the Creative Commons Attribution 4.0 International License (http://creativecommons.org/licenses/by/4.0/), which permits unrestricted use, distribution, and reproduction in any medium, provided you give appropriate credit to the original author(s) and the source, provide a link to the Creative Commons license, and indicate if changes were made. The Creative Commons Public Domain Dedication waiver (http://creativecommons.org/publicdomain/zero/1.0/) applies to the data made available in this article, unless otherwise stated. 
determination, testicular development, and maintenance of male fertility [15].

According to previous research, the expression of $S O X 30$, a member of the Sox category of proteins, is associated with spermatogonial differentiation and spermatogenesis functions in mice and humans $[14,16]$. SOX30 members modulate genetic expression controlling a myriad of processes related to development; however, the regulation may occur at different stages and differ according to sex $[13,17]$. In lung cancer, SOX3O is currently known to be downregulated and affects cellular apoptosis by transcriptionally activating p53 [18]. However, the biological function and clinical significance of SOX3O in BC remain unclear. Our investigations seek to explore how SOX3O is expressed in BC along with its biological roles in regulating cell migration, proliferation, and apoptosis in BC.

\section{Methods}

\section{Patient samples}

In this study, 30 pairs of $\mathrm{BC}$ tissue and normal paracancerous tissue were gained from Zhujiang Hospital (Guangdong, China) and quickly exposed to liquid nitrogen to stimulate freezing post-resection.

\section{Bladder cancer cell lines}

Human BC lines for research:5637(catalog number: ATCC ${ }^{ø}$ HTB- $\left.{ }^{\mathrm{rm}}\right)$, T24(catalog number: ATCC ${ }^{\bullet}$ HTB- $\left.^{\mathrm{rm}}\right)$, SW780(catalog number: ATCC ${ }^{\ominus}$ CRL-2169 ${ }^{\text {TM }}$ ), and J82(cata$\log$ number: ATCC ${ }^{\oplus}$ HTB- $\left.^{\mathrm{rm}}\right)$ and normal bladder cells SV-HUC-1(catalog number: ATCC ${ }^{\oplus}$ CRL-9520 $^{\mathrm{Tm}}$ ) were gained from the American Type Culture Collection. SW780 and 5637 cells were maintained in RPMI 1640 medium, T24 cells in 5A medium, J82 cells in Minimum Essential Medium and SV-HUC-1 cells in F-12 K medium; all culture media contained $10 \%$ fetal bovine serum (FBS, Gibco, Australia).

\section{Extraction of RNA and qRT-PCR}

Cancer cell lines and tumor tissue specimens were subjected to RNA extraction with TRIzol reagent (Ambion) using instructions provided in the product manual. cDNA $(20 \mu \mathrm{l})$ was produced with the help of ReverTra Ace qPCR RT master mix (Toyobo, Japan). The reaction containing $1 \mu \mathrm{g}$ of RNA was maintained for $15 \mathrm{~min}$ at $37^{\circ} \mathrm{C}$, and then for $5 \mathrm{~min}$ at $50{ }^{\circ} \mathrm{C}$ and another $5 \mathrm{~min}$ at $98{ }^{\circ} \mathrm{C}$ followed by exposure to $4{ }^{\circ} \mathrm{C}$ for the remainder of the run. A relative quantitative analysis was performed to determine mRNA expression in tissue samples or cultured cells using a RT-PCR and SYBR Green method. All gene expressions were normalized to $\beta$-Actin. Primer sequences are as follows: SOX30 5' CCAAGCCCT GTCACACTTTT 3'(forward) and 5' AATCCTGTT GGCGCTCTCTA 3'(reverse); $\beta$-actin 5' CAATGACCC
CTTCATTGACC 3'(forward) and 5' GACAAGCTT CCCGTTCTCAG 3'(reverse). The comparative threshold cycle (CT) method was used to calculate the relative mRNA expression levels of SOX30.

\section{Western blot analysis}

$\mathrm{BC}$ cells and $\mathrm{BC}$ tissue samples were rinsed with phosphate-buffered saline (PBS) on ice. An appropriate amount of radioimmunoprecipitation assay (RIPA) buffer (Pierce) mixed with protease inhibitor (1:100 dilution, Thermo scientific, USA) was added. A bicinchoninic acid (BCA) protein assay kit (Pierce) was then used to detect total protein concentrations. Samples were electrophoretically run on a $12 \%$ polyacrylamide gel, and then proteins (20 $\mu \mathrm{g}$ per sample) were applied onto a polyvinylidene difluoride (PVDF) membrane (Millipore, Germany). Protein samples on the membranes were incubated with anti-SOX30 antibodies (1:1500, Santa Cruz Biotechnology, USA) for $60 \mathrm{~min}$ and anti- $\beta$-tubulin antibodies (1:8000, Abcam, UK-E) overnight at $4{ }^{\circ} \mathrm{C}$ along with a small vibration. The following morning, membranes were TBST-rinsed and left for a final incubation with goat anti-rabbit secondary antibodies (1:8000, Abcam, UK-E) for $1 \mathrm{~h}$ on the basis of the internal control. Chemiluminescence imaging instruments were provided by Gene Company Limited.

\section{Culture of stable cell lines}

A lentivirus vector was used to clone full-length SOX30 cDNA along with negative controls (Gene Pharma, China). For transduction, lentiviral constructs expressing SOX30 or the negative control were transduced into 5637 and T24 cells, respectively. SOX30 expression levels were identified via western blot and qRT-PCR.

\section{Cell proliferation}

Quantification of cell proliferation was carried out utilizing a CCK-8 assay (CCK-8, Dojindo, Kumamoto, Japan). T24 or 5637 cells $(100 \mu \mathrm{l}, 2 \times 103$ cells $)$ were planted onto 96-well plates. After 24 h, CCK- 8 solution $(10 \mu \mathrm{l})$ was inserted into 5 wells in the overexpression and negative control groups. Cell proliferation assay was performed according to our previous study [5]. Results were obtained for the overexpression groups and negative control group at different time points (0-4 days) in three independent trials via detection at $450 \mathrm{~nm}$ absorbance.

\section{Cell migration and invasion assays}

To determine the capabilities T24 or 5637 cells to migrate, Transwell chambers were used to conduct the experiment. Approximately $3 \times 104$ transduced cells in $300 \mu \mathrm{l}$ of medium without FBS were loaded onto the higher chamber, with $500 \mu \mathrm{l}$ of medium containing $10 \%$ 
serum placed in the bottom slot. The operation of both the cell migration and invasion assays were similar was similar; however, invasion-related experiments utilized a chamber coated with Matrigel, and then the transduced T24 or 5637 cells were allowed to migrate or invade for $24 \mathrm{~h}$. Bladder cancer cells on the upper chambers were gently eliminated, and cells found on the bottom-most surface were subjected to fixation with $4 \%$ paraformaldehyde for $25 \mathrm{~min}$. Crystal violet $(0.05 \%)$ was used to stain migratory cells. The migration ability of the cells was summed from images of five random microscopic fields per well.

\section{Cellular apoptosis analysis}

Transduced cells were digested using trypsin, centrifuged at $2000 \mathrm{rpm}$ for $3 \mathrm{~min}$, and then resuspending transduced cells $(1 \times 106)$ in $100 \mu \mathrm{l}$ of $1 \times$ binding buffer, which contained and $5 \mu \mathrm{l}$ of PI and $5 \mu \mathrm{l}$ of annexin-VFITC. A 10-15 min incubation in a dark room was carried out for all transduced cells, in accordance to detailed steps described in our previous study [5]. The samples were analyzed via flow cytometry and subjected to three experimental repetitions.

\section{Immunohistochemistry (IHC) analysis}

A paraffin-embedded BC tissue microarray, including 56 pairs of cancerous tissues and 10 pairs of adjacent tissues, was purchased from the Shanghai Biochip Company Ltd. (Shanghai, China). Antigen retrieval with a sodium citrate solution (10 mM, pH 6.0) was performed at a high temperature for $2 \mathrm{~min}$, a low temperature for 10 min twice, and then at room temperature. Samples were then incubated in a $3 \%$ hydroxyl peroxide solution for 10-15 min to reduce nonspecific background staining attributable to endogenous peroxidase; sheep serum was then added for 30 min to block non-specific background staining after washing with PBS twice for $5 \mathrm{~min}$. After the addition of an anti-SOX30 antibody (1:200), samples were left overnight at $4{ }^{\circ} \mathrm{C}$. A $30 \mathrm{~min}$ incubation at $24{ }^{\circ} \mathrm{C}$ followed the next day. Finally, samples were incubated with a biotin-labeled goat anti-rabbit antibody for $30 \mathrm{~min}$, colored with 3,3'-diaminobenzidine and hematoxylinstained. The dyeing times were obtained by observing the extent of color development under a microscope.

\section{Statistical analysis}

Statistically significant differences between BC tissue and para-carcinoma tissue were determined using a paired samples t-test with SPSS 19.0 (SPSS, USA). Analysis of variance (ANOVA) and independent-samples t-test were employed for CCK-8 data analysis and other experimental results, respectively. Chi-squared analysis allowed us to assess the relationship between SOX30 expression and the clinicopathological characteristics of BC. $P<0.05$ indicated a statistical significance.

\section{Results}

SOX30 expression found to be suppressed in human BC tissue and $B C$ cell lines

To determine in vitro SOX30 expressions, $30 \mathrm{BC}$ tissue pairs and adjacent tissues were examined for RNA and protein levels. qRT-PCR results suggested that SOX30 expression was significantly lower in $80 \%$ (23/30) of the $\mathrm{BC}$ tissues than in adjacent cancer tissue (Fig. 1a). We selected 5 pairs of $\mathrm{BC}$ tissue and their corresponding adjacent tissue to measure protein expression via western blotting. SOX30 was expressed to a lower degree in $\mathrm{BC}$ tissues in contrast to healthy bladder tissues adjacent to the tumor. Western blot results were consistent with RNA levels (Fig. 1c). Furthermore, we determined the RNA and protein levels of SOX30 in cell lines. SOX30 expression was significantly lower in BC cells (Fig. 1b and $d, * P<0.01)$ compared to SV-HUC-1 cells and normal bladder tissue.

\section{Low expression of SOX30 conferred worse patient prognosis in those with $\mathrm{BC}$}

IHC staining revealed an elevated $S O X 30$ protein expression in healthy bladder epithelium, and conversely a relatively low expression in BC tissues (Fig. 2). To determine the clinical significance of these molecular differences, further analysis was performed in efforts to correlate clinicopathological features to SOX30 expression. As shown in Table 1, downregulation of SOX30 was significantly related to advanced tumor, node, and metastasis (TNM) stages $(P=0.019$, Table 1$)$, but not to age, sex, tumor size, clinical grade, or pathological type. Overall survival (OS) calculations as evaluated via log-rank tests and Kaplan-Meier curves revealed that a suppressed expression of SOX30 tended to yield poorer patient prognosis $(P=0.0388)$ (Fig. 3$)$.

\section{Generation of cell lines overexpressing SOX30}

We sought to extend current knowledge of SOX30's function in BC by generating SOX30-overexpressing T24 and 5637 cell lines. As shown in Fig. 4a-d, overexpression of SOX30 in these cell lines was successful. Altered T24 and 5637 cells were found to have clearly elevated SOX30 mRNA and protein levels than in the empty vector-transduced control (NC) group.

\section{Overexpression of SOX30 suppresses BC cell proliferation}

Further cell proliferation studies via CCK-8 assays that were done to confirm how SOX30 expressions influenced cell activity revealed that both T24 and 5637 cell lines with high SOX30 expression had a lower 
A

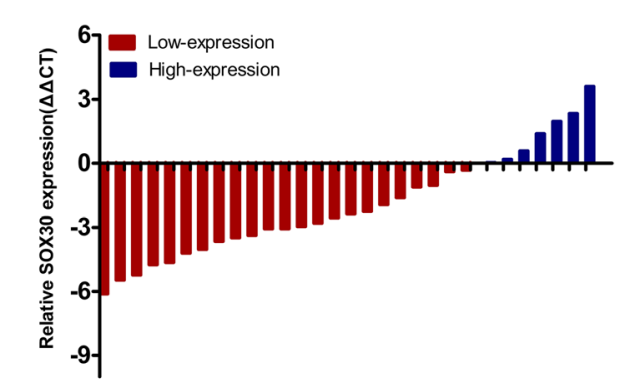

C

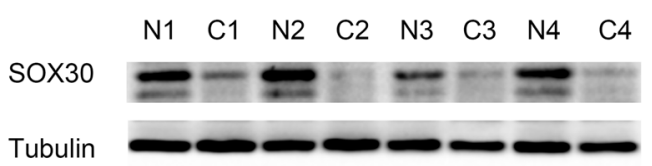

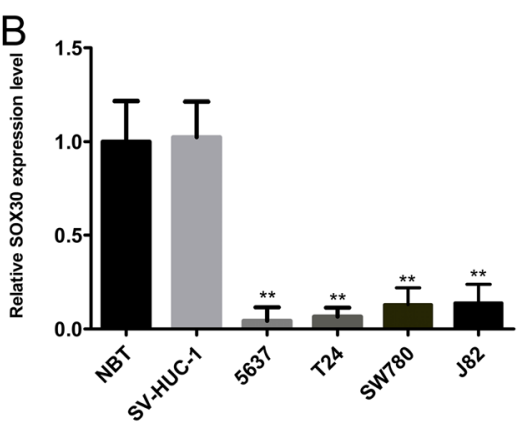

D

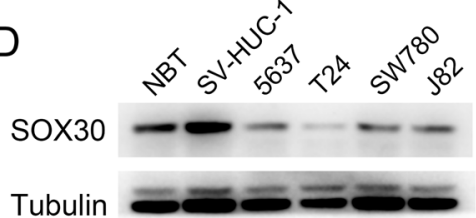

Fig. 1 SRY-box containing gene 30 (SOX30) was downregulated in bladder cancer. Western blotting and real-time quantitative PCR (qRT-PCR) were utilized to quantify SOX30 expression levels. a Bladder cancer tissues had decreased relative SOX30 expression levels. b qRT-PCR revealed that SV-40-immortalized human uroepithelial cells and normal bladder tissues (NBT) had higher SOX30 expression levels compared to T24 and 5637 bladder cancer cell lines. Data is depicted in terms of mean \pm SD. ${ }^{* *} P<0.01$. c Western blotting revealed that pair-matched adjacent normal bladder tissues had higher SOX30 expression levels compared to bladder cancer tissues. d Western blotting uncovered that SV-40-immortalized human uroepithelial cells and NBT had higher SOX30 expression levels compared to T24 and 5637 bladder cancer cell lines

proliferation rate than the T24-NC and 5637-NC groups (Fig. $4 \mathrm{e}-\mathrm{f}$ ).

\section{Overexpression of SOX30 inhibits BC cell migration and invasion}

How SOX3O affected BC cell invasion and migration was investigated with Transwell assays. SOX30 overexpression significantly inhibited migration of 5637 and T24 cell lines (Fig. 5a and b, d and e). Similarly, Matrigel invasion assays indicated that SOX3O overexpression suppressed the invasion ability of T24 and 5637 cells. Our findings demonstrate the ability of SOX30 to attenuate cell invasion and migration in BC cells (Fig. 5a and $c, d$ and $f$ ).

\section{Overexpression of SOX30 increases apoptosis in T24 and 5637 cells}

As previously described, $S O X 30$ inhibits BC cell proliferation. A flow cytometric analysis was conducted to explore how SOX30 affected cellular apoptosis. These experiments demonstrated that SOX30-overexpressing cells experienced elevated apoptotic rates compared to negative control 5637 and T24 cells (Fig. 6). Our findings demonstrate the ability of SOX30 to induce apoptosis in $\mathrm{BC}$ cell lines in vitro.

\section{Discussion}

$\mathrm{BC}$ is a very serious health issue worldwide, with relatively high morbidity and mortality rates [19]. Therefore,

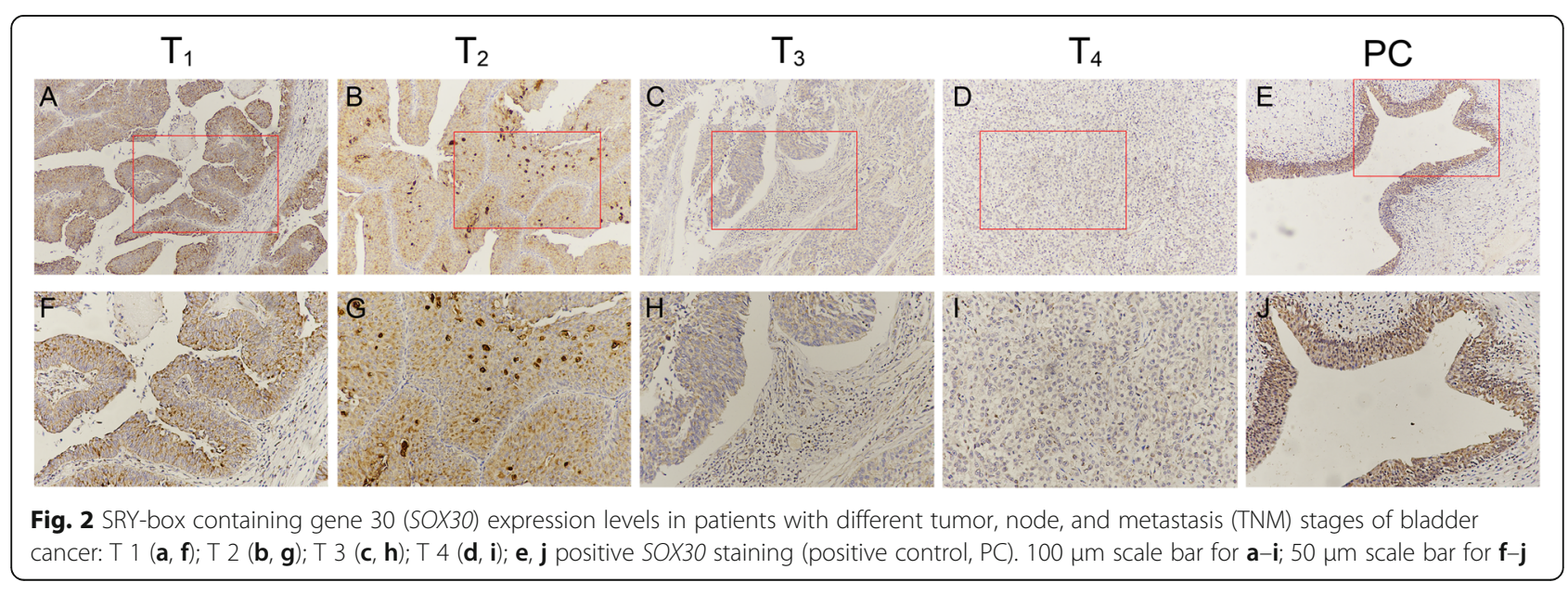


Table 1 Correlation between SOX30 expression and clinicopathological characteristics of bladder cancer patients

\begin{tabular}{|c|c|c|c|c|}
\hline \multirow[t]{2}{*}{ Characteristic } & \multirow{2}{*}{$\begin{array}{l}\text { case number } \\
(n=56)\end{array}$} & \multicolumn{2}{|c|}{ SOX30 expression } & \multirow[t]{2}{*}{$P$-value } \\
\hline & & $\begin{array}{l}\text { High } \\
(n=35)\end{array}$ & $\begin{array}{l}\text { Low } \\
(n=21)\end{array}$ & \\
\hline Gender & & & & 0.639 \\
\hline Male & 47 & 30 & 17 & \\
\hline Female & 9 & 5 & 4 & \\
\hline Age & & & & 0.093 \\
\hline$\geq 60$ years & 44 & 30 & 14 & \\
\hline$<60$ years & 12 & 5 & 7 & \\
\hline TNM stage & & & & $0.019^{\mathrm{a}}$ \\
\hline $\mathrm{T} 1-2$ & 30 & 23 & 7 & \\
\hline T3-4 & 26 & 12 & 14 & \\
\hline N status & & & & 0.138 \\
\hline $\mathrm{N}_{0}$ & 50 & 30 & 20 & \\
\hline $\mathrm{N}_{1-3}$ & 6 & 5 & 1 & \\
\hline Histologic grade & & & & 0.068 \\
\hline $\mathrm{G}_{1-2}$ & 19 & 15 & 4 & \\
\hline $\mathrm{G}_{3-4}$ & 37 & 20 & 17 & \\
\hline Tumor size & & & & 0.150 \\
\hline$\geq 5 \mathrm{~cm}$ & 20 & 15 & 5 & \\
\hline$<5 \mathrm{~cm}$ & 36 & 20 & 16 & \\
\hline Pathological type & & & & 0.317 \\
\hline Urothelium carcinoma & 33 & 18 & 15 & \\
\hline Papillary carcinoma & 13 & 11 & 2 & \\
\hline Squamous-cell carcinoma & 5 & 4 & 1 & \\
\hline Glandular carcinoma & 5 & 2 & 3 & \\
\hline
\end{tabular}

${ }^{a}$ Statistically significant an understanding of the molecular mechanisms and biological functions of $\mathrm{BC}$ development is imminently needed to improve prognosis and treatment outcomes.

To date, approximately 30 SOX genes encoding proteins containing the HMG domain have been found based on structure, organization, similarity, and other characteristics. There are 10 families of genes related to SOX, designated A to J [10, 20, 21]. SOX30 is located on human chromosome $5(5 \mathrm{q} 33)$ and belongs to the $\mathrm{H}$ group; it was initially extracted from mice and humans. Studies suggest that SOX30 exists in both mammals and non-mammals, and it is considered a gonad-specific gene associated with stage and phenotypic sex $[13,14]$. Furthermore, diminished methylation at $\mathrm{CpG}$ islands in SOX30 could promote SOX30 expression in mouse developmental testes, and $S O X 30$ expression can be restored by 5 -aza-2'-deoxycytidine in TM4 (Sertoli), TM3 (Leydig) and GC2 (GC-2 spd - spermatocyte), cell lines [15]. SOX30 expression is downregulated in the human trabecular meshwork via triamcinolone acetonide and dexamethasone treatment [22]. Moreover, SOX30 is silenced by hypermethylation and has been found in lung cancer; SOX30 overexpression inhibits lung cancer cell proliferation, induces cellular apoptosis in vitro, and represses tumor formation in vivo. In addition, the antitumor effects of SOX30 result from attachment to the CACTTTG $(+115$ to +121$)$ region of the p53 promoter, acting as a new transcriptional activating factor of p53 [18]. SOX30 also preferentially activates p53 transcription at the ACAAT motif [14]. In human lung adenocarcinomas, SOX30 expression correlates well with the histological type as well as lymphatic metastasis; high SOX30 expression is related to favorable survival [23]. Recently, Guo et al. [24] observed that SOX30 may act as a miR-645 target in colon cancer.

The present study shows that SOX30 expression is considerably lower in $\mathrm{BC}$ than in adjacent normal tissues and that poor survival in BC as well as advanced TNM stages are significantly linked to lower SOX30 expression ( $P<0.05$ for both). Furthermore, healthy bladder tissue and normal bladder cell lines (SV-HUC-1 cells) expressed higher SOX30 expression in contrast to levels found in $\mathrm{BC}$ cell lines. Interpreted as a whole, these findings allude towards $S O X 30$ 's role in $\mathrm{BC}$ tumorigenesis. To discover the significance of SOX3O in BC, we examined cell apoptosis, invasion, migration as well as proliferation of BC cell lines $\mathrm{T} 24$ and 5637 modified to overexpress SOX30 using a lentiviral vector. The results show that overexpression of SOX30 significantly inhibited cell invasion, migration as well as proliferation while promoting apoptosis in T24 and 5637 cells. As such, overexpression of SOX30 could repress the progression and development of BC. However, the present study is

limited in terms of the number of $\mathrm{BC}$ tissue samples and
Fig. 3 Patients with higher levels of SRY-box containing gene 30 (SOX30) expression showed longer overall survival times than patients with lower levels of SOX30 expression (log-rank $P<0.05$ ) 

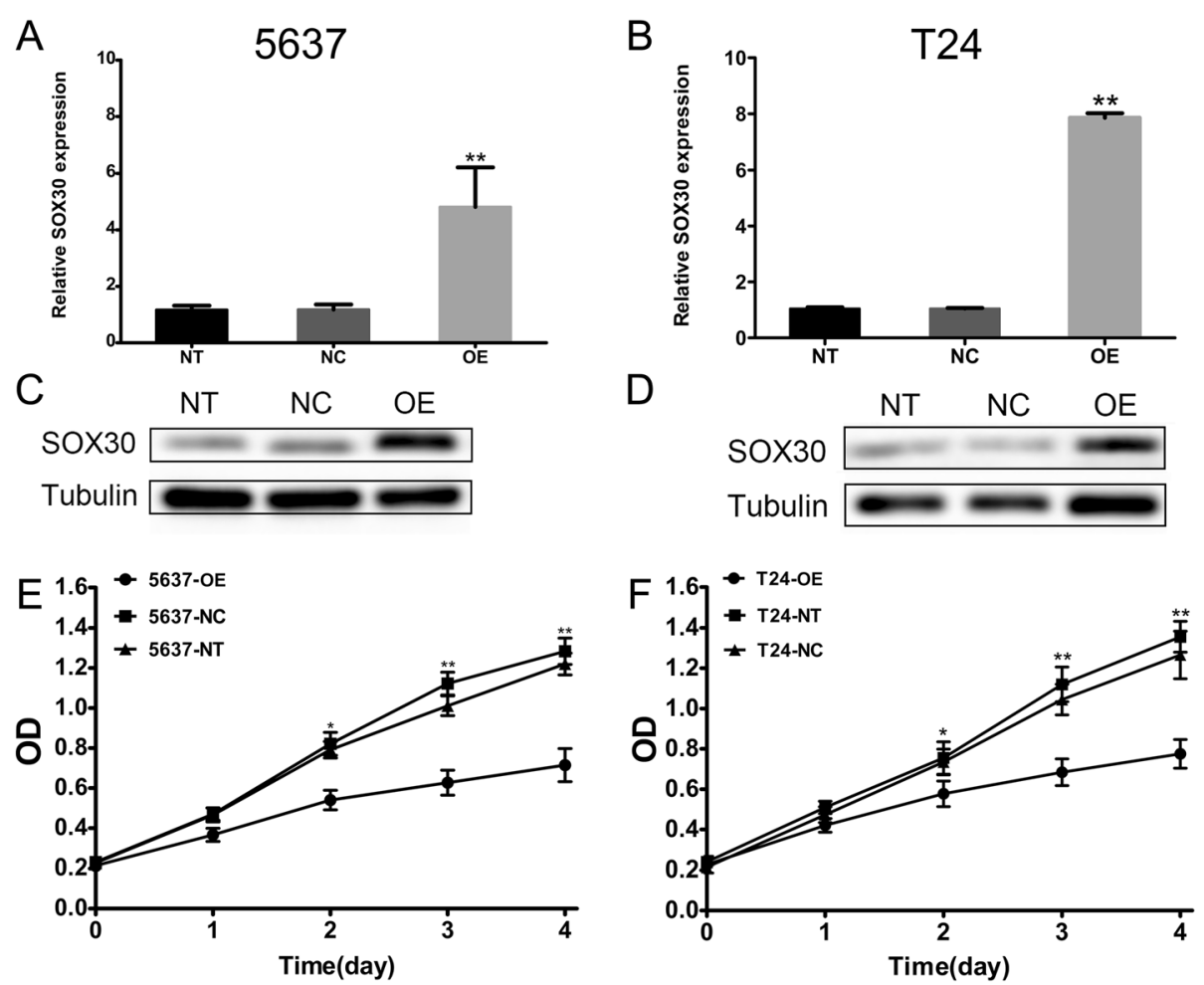

Fig. 4 SRY-box containing gene 30 (SOX30) is overexpressed in T24 and 5637 bladder cancer cell lines. Western blot and qRT-PCR analyses of SOX30 from empty vector-transduced control (NC), non-transduced control (NT) and target gene-transduced cells (OE) are depicted for 5637 (a, c) and T24 (b, d) cells. Overexpression of SRY-box containing gene 30 (SOX30) inhibited proliferation of bladder cancer cell, as revealed via a Cell Counting Kit-8 (CCK-8) assay. Inhibition of cellular proliferation was observed in 5637 (e) and T24 (f) bladder cancer cells. Data is depicted in terms of mean \pm SD. $\left({ }^{*} P<0.05,{ }^{* *} P<0.01\right)$
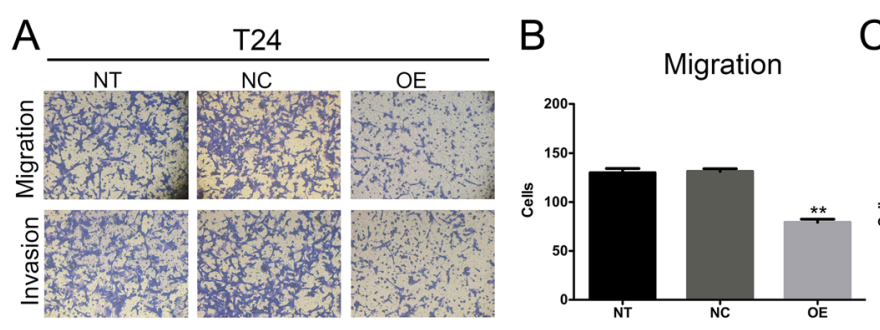

C

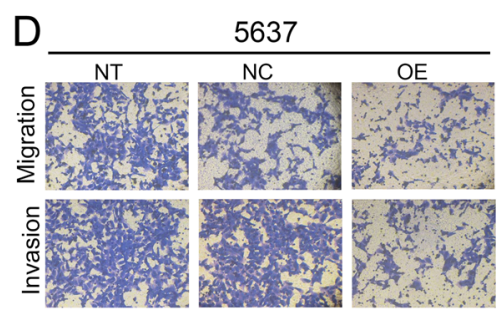

$\mathrm{E}$

$\mathrm{F}$
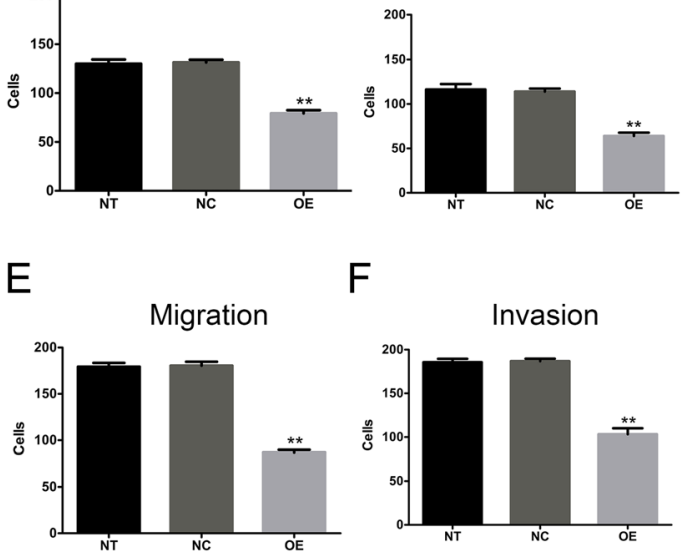

Fig. 5 SRY-box containing gene 30 (SOX30) inhibits 5637 and T24 bladder cancer cell invasion and migration. a-c SOX30 overexpression and its effects on T24 cell invasion and migration are shown. $\mathbf{d}-\mathbf{f}$ SOX30 overexpression and its effects on 5637 cell invasion and migration are shown. Data is depicted in terms of mean \pm SD. ${ }^{* *} P<0.01$. Each assay was performed in triplicate. NT, non-transduced control; NC, empty vector-transduced control; OE, target gene-transduced cells 


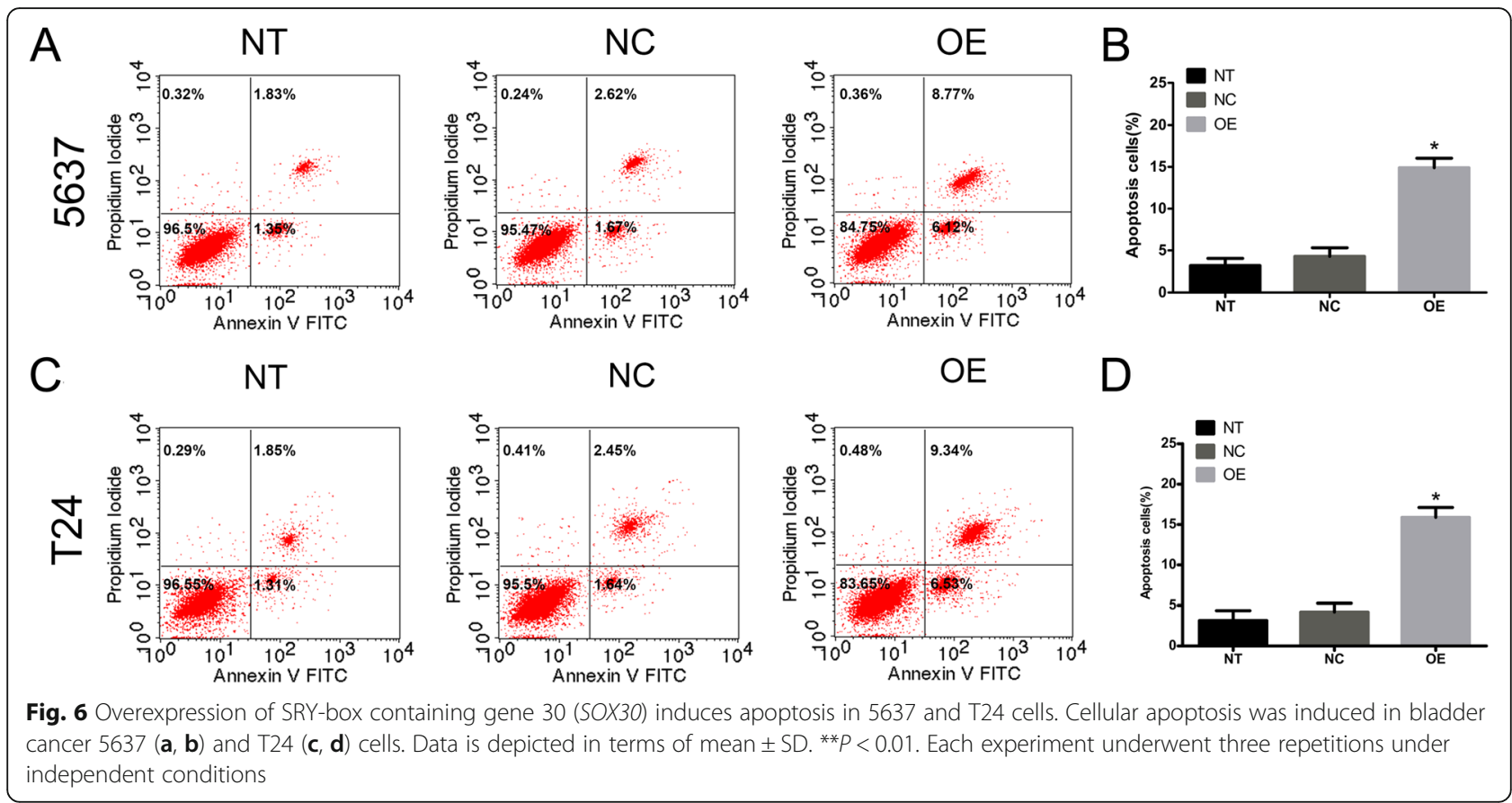

the number of paraffin-embedded bladder cancer tissue samples used in the microarray; therefore, further studies should verify these results using a larger case series. Moreover, this study was just a preliminary analysis, and deeper gene interactions and related signaling pathways need to be further explored.

\section{Conclusion}

This experiment demonstrates that $\mathrm{BC}$ cells express downregulated levels of SOX30, a phenomenon related to poor prognosis and advanced TNM stage. Additionally, SOX30 was also discovered to be a key driver of proliferation, invasion, migration, and apoptosis of $\mathrm{BC}$ cells, suggesting the tumor suppressive function of SOX30. This gene should be further investigated for its prognostic potential as well as its ability to serve as a therapeutic target in treating $\mathrm{BC}$.

\section{Abbreviations}

BC: Bladder cancer; CCK-8: Cell Counting Kit - 8; MIBC: Muscle-invasive bladder cancer; NMIBC: Non-muscle-invasive bladder cancer; SOX30: SRY-box containing gene 30; TCC: Transitional cancer cells; TURBT: Transurethral resection of the bladder tumor

\section{Acknowledgments}

The authors are indebted to all of the donors whose names were not included in the author list, but who joined in our research.

\section{Funding}

This study was supported by funding from the high level university's medical discipline construction (grant no. 2016031638) and the Shenzhen Science and Technology Project (grant no. JSGG 20160301162913683). The funding body had no role in the design of the study and collection, analysis, and interpretation of data and in writing the manuscript.

\section{Availability of data and materials}

The datasets used and/or analysed during the current study are available from the corresponding author on reasonable request.

\section{Authors' contributions}

Study concept and design: YL, HW. Acquisition of data: JHZ, LCW. Analysis and interpretation of data: GY, YTZ, and JHZ. Clinical sample collection and preparation: GY, YTZ. Wrote and revised the manuscript: YL, HW. All authors read and approved the final manuscript. AT provided the financial support and supervised laboratorial processes.

\section{Ethics approval and consent to participate}

All subjects signed an informed consent form. The study was performed according to the Declaration of Helsinki and approved by the Ethics Committee of Shenzhen Second People's Hospital (approval number 20170512001).

Additionally, written consent was obtained from each patient.

\section{Competing interests}

The authors declare that they have no competing interests.

\section{Publisher's Note}

Springer Nature remains neutral with regard to jurisdictional claims in published maps and institutional affiliations.

\section{Author details}

'The Central Laboratory, Shenzhen Second People's Hospital, Graduate School of Guangzhou Medical University, Shenzhen, China. 'Department of Urinary Surgery, Shenzhen Second People's Hospital, The First Affiliated Hospital of Shenzhen University, Shenzhen, China.

Received: 28 December 2017 Accepted: 30 May 2018

Published online: 07 June 2018

\section{References}

1. Kang HW, Kim YH, Jeong P, Park C, Kim WT, Ryu DH, Cha EJ, Ha YS, Kim TH, Kwon TG, et al. Expression levels of FGFR3 as a prognostic marker for the progression of primary pT1 bladder cancer and its association with mutation status. Oncol Lett. 2017;14(3):3817-24. 
2. Guo C, Xiong D, Yang B, Zhang H, Gu W, Liu M, Yao X, Zheng J, Peng B. The expression and clinical significance of ZBTB7 in transitional cell carcinoma of the bladder. Oncol Lett. 2017;14(4):4857-62.

3. Siegel RL, Miller KD, Jemal A. Cancer statistics, 2016. CA Cancer J Clin. 2016; 66(1):7-30.

4. Jacobs BL, Lee CT, Montie JE. Bladder cancer in 2010: how far have we come? CA Cancer J Clin. 2010;60(4):244-72.

5. Wang H, Zhong J, Wu C, Liu Y, Zhang J, Zou X, Chen Y, Su J, Yang G, Zhong $Y$, et al. Stromal antigen 2 functions as a tumor suppressor in bladder cancer cells. Oncol Rep. 2017;38(2):917-25.

6. Zhang D, Sun G, Zhang H, Tian J, Li Y. Long non-coding RNA ANRIL indicates a poor prognosis of cervical cancer and promotes carcinogenesis via PI3K/Akt pathways. Biomed Pharmacother. 2017:85:511-6.

7. Sofra M, Fei PC, Fabrizi L, Marcelli ME, Claroni C, Gallucci M, Ensoli F, Forastiere E. Immunomodulatory effects of total intravenous and balanced inhalation anesthesia in patients with bladder cancer undergoing elective radical cystectomy: preliminary results. J Exp Clin Cancer Res. 2013;32:6.

8. Liu J, Gong X, Zhu X, Xue D, Liu Y, Wang P. Rab27A overexpression promotes bladder cancer proliferation and chemoresistance through regulation of NF-kappaB signaling. Oncotarget. 2017;8(43):75272-83.

9. Racioppi M, D'Agostino D, Totaro A, Pinto F, Sacco E, D'Addessi A, Marangi F, Palermo G, Bassi PF. Value of current chemotherapy and surgery in advanced and metastatic bladder cancer. Urol Int. 2012;88(3):249-58.

10. Bowles J, Schepers G, Koopman P. Phylogeny of the SOX family of developmental transcription factors based on sequence and structural indicators. Dev Biol. 2000;227(2):239-55.

11. Collignon J, Sockanathan S, Hacker A, Cohen-Tannoudji M, Norris D, Rastan S, Stevanovic M, Goodfellow PN, Lovell-Badge R. A comparison of the properties of Sox-3 with Sry and two related genes, Sox-1 and Sox-2. Development. 1996;122(2):509-20.

12. Hacker A, Capel B, Goodfellow P, Lovell-Badge R. Expression of Sry, the mouse sex determining gene. Development. 1995;121(6):1603-14.

13. Han F, Wang Z, Wu F, Liu Z, Huang B, Wang D. Characterization, phylogeny, alternative splicing and expression of Sox30 gene. BMC Mol Biol. 2010;11:98.

14. Osaki E, Nishina Y, Inazawa J, Copeland NG, Gilbert DJ, Jenkins NA, Ohsugi M, Tezuka T, Yoshida M, Semba K. Identification of a novel Sry-related gene and its germ cell-specific expression. Nucleic Acids Res. 1999;27(12):2503-10,

15. Han F, Dong Y, Liu W, Ma X, Shi R, Chen H, Cui Z, Ao L, Zhang H, Cao J, et al. Epigenetic regulation of sox30 is associated with testis development in mice. PLoS One. 2014;9(5):e97203.

16. Ballow D, Meistrich ML, Matzuk M, Rajkovic A. Sohlh1 is essential for spermatogonial differentiation. Dev Biol. 2006;294(1):161-7.

17. De Martino SP, Errington F, Ashworth A, Jowett T, Austin CA. sox30: a novel zebrafish sox gene expressed in a restricted manner at the midbrain-hindbrain boundary during neurogenesis. Dev Genes Evol. 1999;209(6):357-62.

18. Han F, Liu W, Jiang X, Shi X, Yin L, Ao L, Cui Z, Li Y, Huang C, Cao J, et al. SOX30, a novel epigenetic silenced tumor suppressor, promotes tumor cell apoptosis by transcriptional activating p53 in lung cancer. Oncogene. 2015; 34(33):4391-402.

19. Zhang M, Ren B, Li Z, Niu W, Wang Y. Expression of N-Myc downstreamregulated gene 2 in bladder Cancer and its potential utility as a urinary diagnostic biomarker. Med Sci Monit. 2017;23:4644-9.

20. Schepers GE, Teasdale RD, Koopman P. Twenty pairs of sox: extent, homology, and nomenclature of the mouse and human sox transcription factor gene families. Dev Cell. 2002;3(2):167-70.

21. Wilson MJ, Dearden PK. Evolution of the insect sox genes. BMC Evol Biol. 2008;8:120.

22. Fan BJ, Wang DY, Tham CC, Lam DS, Pang CP. Gene expression profiles of human trabecular meshwork cells induced by triamcinolone and dexamethasone. Invest Ophthalmol Vis Sci. 2008;49(5):1886-97.

23. Han F, Liu W, Xiao H, Dong Y, Sun L, Mao C, Yin L, Jiang X, Ao L, Cui Z, et al. High expression of SOX30 is associated with favorable survival in human lung adenocarcinoma. Sci Rep. 2015;5:13630.

24. Guo ST, Guo XY, Wang J, Wang CY, Yang RH, Wang FH, Li XY, Hondermarck $\mathrm{H}$, Thorne RF, Wang YF, et al. MicroRNA-645 is an oncogenic regulator in colon cancer. Oncogenesis. 2017;6(5):e335.

\section{Ready to submit your research? Choose BMC and benefit from:}

- fast, convenient online submission

- thorough peer review by experienced researchers in your field

- rapid publication on acceptance

- support for research data, including large and complex data types

- gold Open Access which fosters wider collaboration and increased citations

- maximum visibility for your research: over $100 \mathrm{M}$ website views per year

At BMC, research is always in progress.

Learn more biomedcentral.com/submissions 